\title{
A STUDY ON FIRE SAFETY ON RESIDENTIAL AND COMMERCIAL CONSTRUCTION SITES
}

\author{
C. SIVAKUMAR ${ }^{1}$, R. MALATHY ${ }^{2}$, P. SIVAPRAKASH ${ }^{3}$
}

\begin{abstract}
The construction industry in India is the country's second largest industrial sector, after agriculture. The construction industry makes a remarkable contribution to the Indian economy and provides employment to a large number of people of India. Fire is a chemical reaction of a combustible substance with oxygen, involving heat and is usually accompanied by a visual flame or incandescence. Ensuring fire safety has always been a challenge to the stakeholders, i.e. building owners, construction companies, contractors and sub-contractors, and government employees due to the multiplicity of the factors involved and their complexity. There are various legal standards and requirements for ensuring fire safety on construction sites. The buildings are normally provided with firewalls during construction and these firewalls separate two structures or divide a structure into smaller portions to prevent the spread of fire. The lightweight construction and trusses are designed to support only their own weight. During a fire, if one fails, a domino effect happens and all fail rapidly within 5 to 10 minutes. Prolonged exposure to fire may result in structural collapse and injury or death of the occupants of the building under construction. Fire safety on construction sites is still in its primitive stages in India. There is a great necessity to improve fire safety on construction sites to protect construction workers and other occupants of the buildings. This study aims to design and implement fire safety systems for construction sites, thereby enhancing the standards to meet the system requirements at par with global standards.
\end{abstract}

Keywords: Construction Safety, Construction Sites, Fire Safety, Hazards.

\footnotetext{
${ }^{1}$ Eng., Anna University, Chennai - 600025 , India, manojsivasuba@gmail.com

${ }^{2}$ Prof.,Ph.D., Eng.,Sona College of Technology, Salem - 636005, India, malathy1968@gmail.com

${ }^{3}$ Asso. Prof.,Ph.D., Eng.,A.S.L.Pauls College of Engineering and Technology, Coimbatore - 641032, India, drpsivaprakash@gmail.com
} 


\section{INTRODUCTION}

The National Building Code of 2016 provides standards and guidelines for construction and fire safety for construction sites. The Building and Other Construction Workers (Regulation of Employment and Conditions of Service) Act of 1996 and The Building and Other Construction Workers (Regulation of Employment and Conditions of Service) Central Rules of 1998 as well as various other state rules provide legal framework for ensuring fire safety on construction sites. The emergencies on construction sites due to fire are capable of causing devastating consequences on the buildings and workers employed there [Littlewood et al., 2017]. Emergency plans provide for various actions, such as evacuation routes and assembly points by moving through escape routes [Ignacio Aedo, 2012]. Clarke (1999) explained the various safety management techniques for building construction sectors. Rafiq et al. (2007) reviewed the concepts of organizational culture, safety culture, summaries of safety culture definitions and research, models and measurements of safety culture within construction safety. Alison et al. (2002) studied various management practices and discussed the most effective practices for reducing employee injury rates. Ann et al. (1997) studied the development of safety awareness in various working environments.

The objectives of this study are:

- To ascertain the perception of fire safety in residential and commercial building characteristics.

- To provide a systematic and objective approach to assess hazards and their associated risks to fire safety.

- To ensure fire safety and enable effective fire emergency planning.

- To alert employers and employees on potential fire hazards at construction sites.

- To draw a status report on fire safety in construction sites; and to design a comprehensive fire safety system for the construction industry.

- To suggest measures and strategies to enhance fire safety in residential and commercial buildings.

- Enable industries, regulatory bodies, workers, management and planners to use the empirical findings of this study. 


\section{RESEARCH METHODOLOGY}

\subsection{RESEARCH PROCESS}

This research process includes five stages.Namely, problem identification, research design, data collection, data analysis, and interpretation of results. It helps the researcher to frame the objective of the research, to decide the data needed for the study and the method of collecting said data, the tools used for collection, and the sample size [Jane Sutton, Zubin Austin, 2015]. The research was conducted by the design and implementation of a fire safety system for construction sites.

\subsection{OBJECTIVES OF STUDY ASSESSMENT}

Based on the frame work of the study and review of existing literature in the field of fire safety at construction sites, the following study assessment has been formulated.

- To find out the mean and standard deviation (S.D.) of factors of fire safety at construction sites perceived by respondents.

- To know the mean and S.D. of factors of fire safety perceived by a group of respondents on residential and commercial construction sites.

- To find out the percentage of responses given by the respondents of the residential and commercial construction sites on fire safety.

- To find out the correlation co-efficient of the factors of the fire safety system involved.

- To assess the performance of fire safety according to the factors considered.

\subsection{STRATEGIES OF THE COLLECTION OF DETAILS}

- Physical observation and collecting data through actual visits to the residential and commercial construction sites.

- To find out the respondents' perception towards fire safety via structured questionnaire statements.

- The prevalent data collected has to be cross-checked for physical verification with supportive facts gathered from records. 
- Sampling techniques for certain inferences about the characteristics of the population are drawn using the stratified simple random sampling method for data collection.

\subsection{DATA REQUIRED FOR THE STUDY}

In this study, a primary and a secondary source of data was collected. The primary sources of data collection were from the residential and commercial construction sites directly through questionnaires given to the management personnel of these construction sites and to the managers and supervisors involved (directly or indirectly). The secondary source of data consists of information gathered from the publication of international organization such as the International Labour Organization, the Occupational Safety and Health Administration (OSHA) of the U.S.A, ISO and OHSAS standards, and the Directorate General Factory Advice Service and Labour Institutes (DGFASLI) of the Government of India.

\subsection{SAMPLE SELECTION AND SIZE}

Expert-validated questionnaires were administered to sixty residential and fifty commercial construction sites, out of which fifty-five residential and fifty-three commercial construction sites provided a response [Anup et al., 2015]. After validation of the questionnaires for completion, only fifty residential and fifty commercial construction sites fulfilled the requirements of the research study, and these were taken into consideration. Standard mean deviation, correlation and statistical significance were studied and analyzed by using ANOVA software for data collected from the administered research tool.

\subsection{RESEARCH TOOLS}

To measure the level of fire safety on a construction site, an investigation was done to develop a questionnaire through a vast coverage of the review of literature in the field of fire safety systems on construction sites. The investigation was designed by a questionnaire which was developed based on the guidelines given in the Factories Act of 1948, The Building and Other Construction Workers (Regulation of Employment and conditions of services) Act of 1996, the Central Rules of 1998, BIS Code 14489, OHSAS 18001, National and International Standards, and the conventions, recommendations, and 
guidelines of the International Labor Organization. The questionnaire was designed with a bipolar response of "Yes" and "No".

The formula for KR-20 for a test with $K$ test items numbered $i=1$ to $K$ is

$$
r=\frac{K}{K-1}\left[1-\frac{\sum_{i=1}^{K} p_{i} q_{i}}{\sigma_{X}^{2}}\right]
$$

where $p_{i}$ is the proportion of correct responses to test item $i, q_{i}$ is the proportion of incorrect responses to test item $i$ (so that $p_{i}+q_{i}=1$ ), and the variance for the denominator is

$$
\sigma_{X}^{2}=\frac{\sum_{i=1}^{n}\left(X_{i}-\bar{X}\right)^{2}}{n}
$$

where $n$ is the total sample size.

If it is important to use unbiased operators, the sum of the squares should be divided by degrees of freedom $(n-1)$, and the probabilities are multiplied by

$$
\frac{n}{n-1}
$$

In this study the researcher followed the KR 20 technique and the reliability value was found to be 0.99 . The subjects were asked to respond YES or NO based on their individual site conditions. Each item in the factor was rated with "YES" having the value of 1 and "NO" having the value of 0 . The sums of the total of each factor explain the perception of the respondents. The minimum possible score is " 0 " and the maximum score is " 40 " for each major element, and the overall total possible score is " 120 ".

The major and minor elements of the Research Tool are: Sources of Ignition, Combustible Materials, Sources of Oxygen, Structural Features, Means of Escape and Escape Times, Signage, Fire Extinguishers, and Emergency Planning. 


\section{DATA COLLECTION AND ANALYSIS}

The information collected from the records as well from personal observations made on site is supplemented through the information elicited from discussion with plant personnel: managers/site incharges, floor supervisors, and workers regardless of their level. The data collected from the respondents was statistically analyzed by using mean, standard deviation, correlation, and the 'E'-test (test of significance of mean difference between two independent variables). Analysis of variance (ANOVA) software is used for the estimation of the amount of total variation in the sample data which is expressed as the sum of its non-negative components. The frequencies, means and standard deviations were calculated for the data obtained and hypotheses were analyzed using one-way ANOVA tests for statistical significance for the differences in means.

Fire safety analysis was carried out on 50 commercial and residential construction sites and the observed safety statuses are shown in Fig.1. The ANOVA analysis is shown in Table.1. Fire safety analysis contains a few aspects such as availability of suitable firefighting equipment, whether the equipment is used in accordance with the manufacturer's recommendations and properly maintained, whether the electrical equipment is prevented from overloading, whether safe smoking areas for staff and service users are demarcated, and whether sources of combustion are kept away. It can be seen that the residential buildings satisfy overall fire safety conditions better than commercial buildings.

A study on combustible materials was carried out on 50 commercial and 50 residential construction sites and the observed status is shown in Fig.2. ANOVA results are shown in Table.2. General housekeeping, arrangements for waste disposal to prevent its build-up, flammable substances handled, transported, and stored, and availability of the required fire safety information are some of the features studied under the safety of combustible materials. Figure 2 illustrates that combustible materials and their safety are operated and maintained in a better manner at commercial buildings than at residential building sites. 


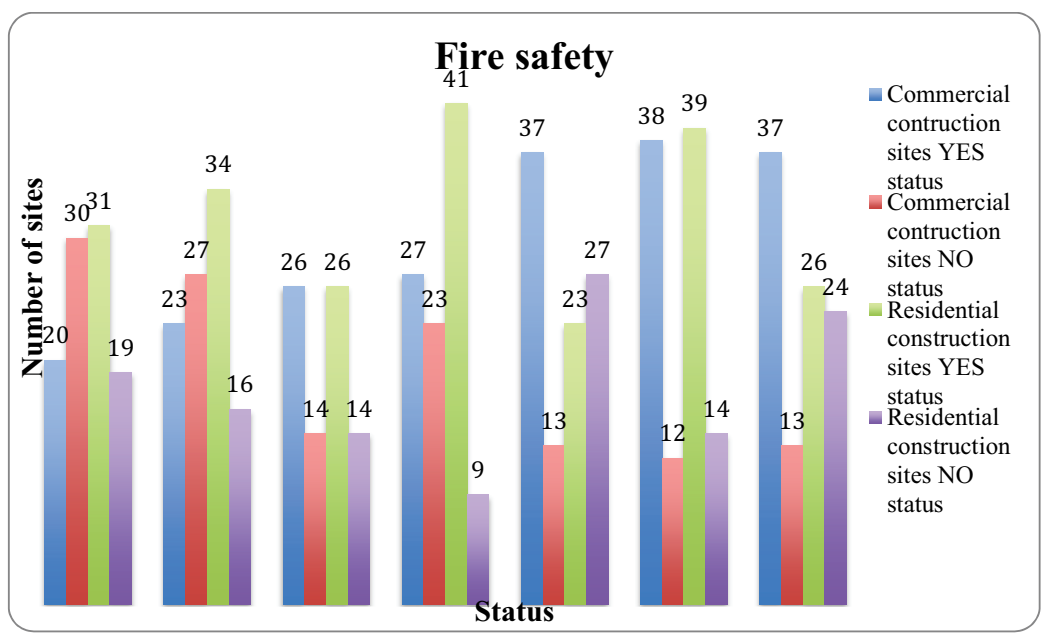

Figure 1. Fire Safety at Residential and Commercial Construction Sites

Table 1 - Two-way ANOVA for Fire Safety

\begin{tabular}{|l|c|c|c|c|c|c|}
\hline $\begin{array}{c}\text { Source of } \\
\text { Variation }\end{array}$ & SS & Df & MS & F & P-value & F crit \\
\hline Rows & 253.4286 & 6 & 42.2381 & 0.6892 & 0.66864 & 4.283866 \\
\hline Columns & 10.28571 & 1 & 10.28571 & 0.167832 & 0.69627 & 5.987378 \\
\hline Error & 367.7143 & 6 & 61.28571 & & & \\
\hline Total & 631.4286 & 13 & & & & \\
\hline
\end{tabular}




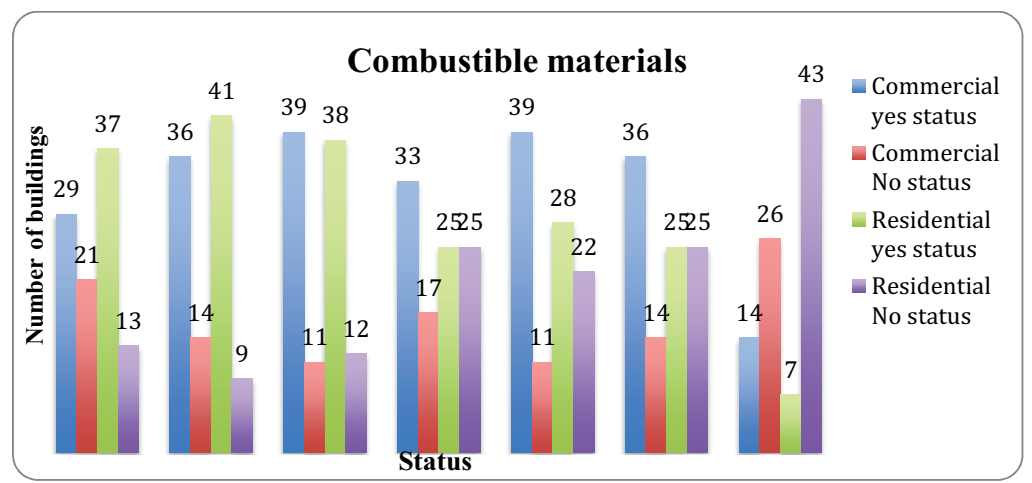

Figure 2. Combustible Materials at Residential and Commercial Construction Sites

Table 2. Two-way ANOVA for Combustible Materials

\begin{tabular}{|l|l|l|l|l|l|l|}
\hline Source of Variation & SS & Df & MS & F & P-value & F crit \\
\hline Rows & 1091 & 6 & 181.8333 & 6.134137 & 0.022075 & 4.283866 \\
\hline Columns & 44.64286 & 1 & 44.64286 & 1.506024 & 0.26571 & 5.987378 \\
\hline Error & 177.8571 & 6 & 29.64286 & & & \\
\hline Total & 1313.5 & 13 & & & & \\
\hline
\end{tabular}

A study on structural features was carried out at 50 commercial and 50 residential construction sites and the observed status is shown in Fig.3. ANOVA results are shown in Table.3. Figure 3 illustrates that, generally commercial buildings satisfy the overall structural feature parameter conditions better than residential buildings. 


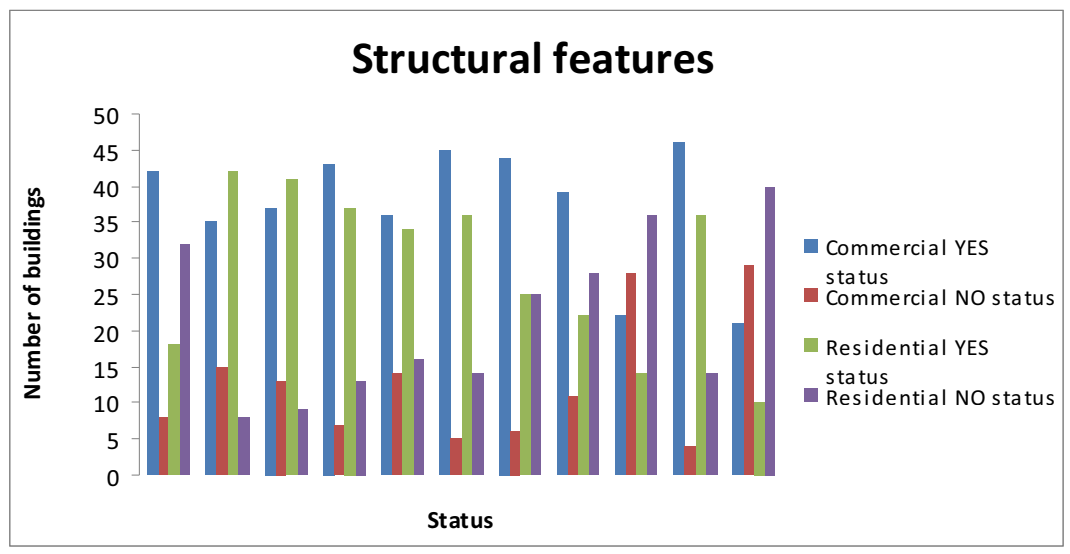

Figure 3. Structural Features at Residential and Commercial Construction Sites

Table 3. Two-way ANOVA for Structural Features

\begin{tabular}{|l|l|l|l|l|l|l|}
\hline $\begin{array}{l}\text { Source of } \\
\text { Variation }\end{array}$ & SS & Df & MS & F & P-value & F crit \\
\hline Rows & 1576.455 & 10 & 157.6455 & 3.596972 & 0.027816 & 2.978237 \\
\hline Columns & 410.2273 & 1 & 410.2273 & 9.360091 & 0.012056 & 4.964603 \\
\hline Error & 438.2727 & 10 & 43.82727 & & & \\
\hline Total & 2424.955 & 21 & & & & \\
\hline
\end{tabular}

Emergency planning analysis was carried out at 50 commercial and 50 residential construction sites and the observed safety status are shown in Fig.4. ANOVA results are shown in Table.4. Figure 4 illustrates that commercial buildings satisfy overall emergency planning features better when compared to residential buildings. 


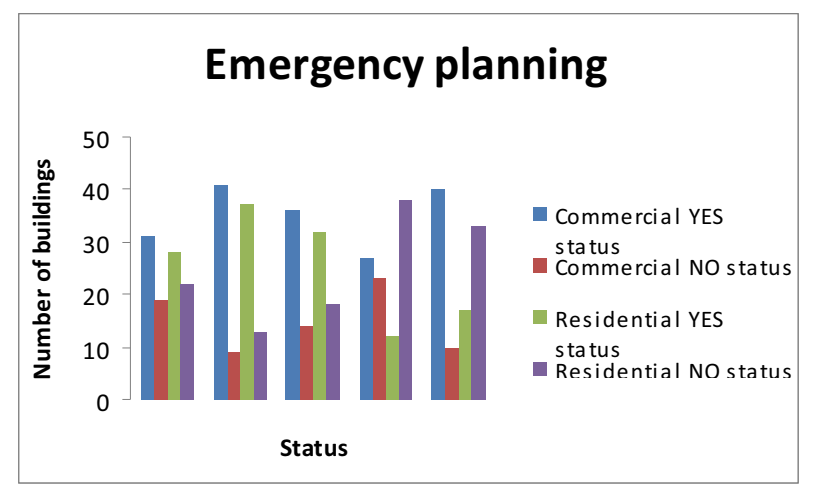

Figure 4. Emergency Planning at Residential and Commercial Construction Sites

Table 4. Two-way ANOVA for Emergency Planning

\begin{tabular}{|l|l|l|l|l|l|l|}
\hline Source of Variation & SS & Df & MS & F & P-value & F crit \\
\hline Rows & 419.4 & 4 & 104.85 & 2.664549 & 0.182757 & 6.388233 \\
\hline Columns & 240.1 & 1 & 240.1 & 6.101652 & 0.068935 & 7.708647 \\
\hline Error & 157.4 & 4 & 39.35 & & & \\
\hline Total & 816.9 & 9 & & & & \\
\hline
\end{tabular}

\section{DISCUSSION OF THE FINDINGS}

Specific findings of this research study are as follows:

- Residential buildings satisfy overall fire safety conditions better than commercial buildings.

- Combustible materials are stored and maintained in a better manner in commercial buildings than in residential buildings.

- Commercial buildings satisfy overall structural feature parameters better than residential buildings. 
- Fire extinguishers, signage, and emergency planning in commercial buildings are better than in residential buildings.

Overall findings of the research study are given as follows:

Fire safety and risk assessment compliances such as provision and maintenance of fire extinguishers, escape routes, displays, emergency action plans, etc., are better in commercial buildings than in residential buildings. However, both the commercial and residential buildings need to focus more on reducing risk and on improving fire safety and fire risk assessment standards and compliances regarding the protection of people working at the construction sites. Fire safety compliances is better in commercial buildings than in residential buildings. Increased compliance in fire safety ensures better workplaces which are free from workplace hazards. It also reduces legal complications at construction sites, ensuring smoother functioning of everyday business protocol.

\section{CONCLUSION}

The subject of construction safety in India is in an emerging stage and its progress at construction sites is increasing after the enactment and implementation of rules and regulations present since 1996. This research study was carried out in order to understand the statuses of safety at residential and commercial construction sites. Furthermore, the implementation of the findings of this study will enhance knowledge and awareness among workers, management, and staff at construction sites, thus making work places safer and healthier by protecting the second largest workforce in India, by enhancing fire safety standards at construction sites. 


\section{REFERENCES}

1. Littlewood, J. R, Alam, M, Goodhew, S, Davies, G, The 'Safety Gap' in buildings: Perceptions of Welsh Fire Safety Professionals, Energy Procedia 134: 787 - 796, 2017.

2. Ignacio Aedo, Shuxin Yu, Paloma Díaz, Pablo Acuna, Teresa Onorati, Personalized Alert Notifications and Evacuation Routes in Indoor Environments, Sensors (Basel). 12(6): 7804 7827, 2012.

3. Jane Sutton, Zubin Austin, Qualitative Research: Data Collection, Analysis, and Management, The Canadian Journal of Hospital Pharmacy. 68(3): 226 - 231, 2015.

4. The Building and Other Construction Workers (Regulation of Employment and Conditions of Service) Act, 1996.

5. The Building and Other Construction Workers (Regulation of Employment and Conditions of Service) Central Rules, 1998.

6. The Factories Act, 1948.

7. AnupW S, Arun Kumar H, SNA Saqhi, Study of Quality Management System in Construction, International Research Journal of Engineering and Technology, 2(2): 462 - 467, 2015.

8. Clarke, T. Managing Health and Safety in Building and Construction. Butterworth Heinemann, England, 1999.

9. Rafiq M Choudhry, Dongping Fang, Sherif Mohamed. The nature of safety culture: A survey of the state - of - the - art. Safety Science. 45: 993 - 1012, 2007.

10. Alison G. Vredenburgh., Organizational Safety, Which management practices are most effective in reducing employee injury rates?. Journal of Safety Research. 33(2): 259 - 276, 2002.

11. Ann M. Williamson, Anne Marie Feyer, David Cairns, Deborah Biancotti. The development of a measure of safety climate: The role of safety perceptions and attitudes. Safety Science. 25(1-3):15 $-27,1997$. 


\section{LIST OF FIGURES AND TABLES:}

Fig. 1. Status of Fire Safety at Residential and Commercial Construction Sites

Rys. 1. Status bezpieczeństwa przeciwpożarowego w budynkach mieszkalnych i komercyjnych

Fig. 2. Combustible Materials at Residential and Commercial Construction Sites

Rys. 2. Materiały palne w budynkach mieszkalnych i komercyjnych

Fig. 3. Structural Features at Residential and Commercial Construction Sites

Rys. 3. Cechy konstrukcyjne w budynkach mieszkalnych i komercyjnych

Fig. 4. Emergency Planning at Residential and Commercial Construction Sites

Rys. 4. Planowanie awaryjne w budynkach mieszkalnych i komercyjnych

Tab. 1. Two-way ANOVA for Fire Safety

Tab. 1. Dwukierunkowa ANOVA dla bezpieczeństwa przeciwpożarowego

Tab. 2. Two-way ANOVA for Combustible Materials

Tab. 2. Dwukierunkowa ANOVA dla materiałów palnych

Tab. 3. Two-way ANOVA for Structural Features

Tab. 3. Dwukierunkowa ANOVA dla cech konstrukcyjnych

Tab. 4. Two-way ANOVA for Emergency Planning

Tab. 4. Dwukierunkowa ANOVA dla planowania awaryjnego 


\section{BADANIE DOTYCZĄCE BEZPIECZEŃSTWA PRZECIWPOŻAROWEGO W BUDYNKACH MIESZKALNYCH I KOMERCYJNYCH}

Słowa kluczowe: bezpieczeństwo konstrukcji, place budowy, bezpieczeństwo przeciwpożarowe, zagrożenia.

\section{STRESZCZENIE:}

Przemysł budowlany w Indiach jest drugim co do wielkości sektorem przemysłowym po rolnictwie. Istnieją różne normy i wymogi prawne dotyczące zapewnienia bezpieczeństwa przeciwpożarowego na placach budowy. Szczególnie konieczna jest poprawa bezpieczeństwa przeciwpożarowego na placach budowy, w celu ochrony pracowników budowlanych i innych osób przebywających w budynku. W niniejszej pracy dokonano analizy bezpieczeństwa przeciwpożarowego w pięciu etapach, a mianowicie identyfikacji problemu, projektu badań, zbioru danych, analizy danych i interpretacji wyników. Ankiety zatwierdzone przez ekspertów zostały sporządzone w celu dokonania pomiaru poziomu bezpieczeństwa przeciwpożarowego na placach budowy. Analiza bezpieczeństwa przeciwpożarowego została przeprowadzona w 50 budynkach mieszkalnych i komercyjnych, a ponadto odnotowano stan bezpieczeństwa. Wyniki badania podkreślają, że zarówno budynki komercyjne, jak i mieszkalne muszą bardziej koncentrować się na zmniejszaniu ryzyka oraz ulepszaniu standardów oceny bezpieczeństwa przeciwpożarowego i ryzyka pożaru. 